\title{
Designing A Graduate Curriculum: Use Of Credentials To Enhance Student Portfolios
}

Rosilyn H. Overton, (E-mail: roverton@njcu.edu), New Jersey City University

\begin{abstract}
Designing a graduate curriculum that meets the needs of the student not planning to pursue an academic career is challenging. Students want a recognized degree that nonetheless delivers content immediately relevant to their career tasks and credible to their employers. Innovative programs with career content are in high demand, but in the process of innovation standards of scholarship, critical thinking and knowledge must be upheld. This paper describes how teaching and learning concepts and principles were used to combine demands of career and scholarship into an innovative graduate program. The environmental scan leading to this design predicated a design that uses national professional credentials as one method of assessment. The curriculum provides students with portfolios validating their work during and at the end of a Master of Science program. Instead of a thesis, students create a capstone project combining scholarship with an employer-ready portfolio. Suggestions are made concerning the transfer of the methodology to practically any discipline.
\end{abstract}

\section{Introduction}

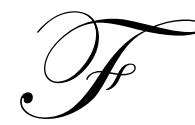

or many years, the business administration graduates of New Jersey City University have requested that the University offer graduate degrees in business. In response, a few years ago the needs of the accounting graduates were met by the inception of a Master of Science in Accounting. However, an accounting degree was not suitable for many people, so another graduate offering was proposed. Initially, the expectation of the faculty of the Department of Business Administration and the College of Professional Studies was that a Master of Business Administration would be the most appropriate next offering, but a focus group with business leaders from the community revealed that the business community was more interested in graduate certificates and specialized degrees than in the generalist Master of Business Administration.

Having learned that area businesses had this preference, the department set about designing a traditional Master of Science in Finance (the degree most mentioned by potential employers) and started considering possible certificates. As results came in from surveys of potential students, it became evident that there was a strong interest in certifications granted by national examination. Based on conferences and development of the faculty, there was interest in giving our students a portfolio of work to show employers and prospective employers. With this in mind, members of the department decided to perform an extensive environmental scan to determine the specialized degree for which there would be the most demand, and also to ascertain which of the many possible certificates would best serve the needs of the University's region. The result of the scan revealed that there was strong interest in the Master of Science in Finance, and that there were three national certifications that presented a combination of marketability, suitability for concentrations in a Master of Science in Finance, and congruence with the qualifications of faculty already in place within the department, minimizing but not eliminating the need for additional faculty.

Although a traditional curriculum for a Master of Science in Finance had already been proposed, there developed the notion of including preparation for one or more of the national certification within the graduate 
curriculum. A comparison of the topics tested on the national examination with the learning outcomes that had been developed for the Master of Science in Finance revealed great congruency. From this basis, the curriculum was modified to one that had at its heart a core curriculum in finance plus a choice of one of three concentrations: financial planning, financial analysis and financial management. Learning outcomes originally in the traditional curriculum were retained, although course order and learning outcomes for each course were modified.

Each concentration is defined by six courses. Those six courses each comprise a graduate certificate that will prepare the student for the national examination for the corresponding certification. While recognizing that some potential students will be intimidated by the academic rigor of graduate level certificates in which the students take courses that are part of a master's degree curriculum, it is the opinion of the department that over the long run, this quality approach will result in better quality applicants, better quality graduates, an enhanced reputation for the University and ultimately, more students.

\section{Environmental Scan Leading to the Design}

\section{The Focus Group}

The focus group to determine area business needs for graduate studies in business was held at the Harborside area of Jersey City, New Jersey at one of the major hotels. Sometimes referred to as Wall Street West, the Harborside area houses many national and international companies in the financial services industry. It is the source of most new employment in the area Invitations were sent to business leaders in the firms at Harborside, and to members of the Small Business Council located in the Jersey City area. Nineteen individuals representing more than 20,000 employees attended the focus group, including representatives of major financial firms, large telecommunications firms, the hospitality industry and small business, as well as members of the NJCU Department of Business Administration Faculty. In the course of approximately three hours, the business leaders responded to prepared and extemporaneous questions about a proposed Master of Business Administration degree. Included were some open ended questions designed to elicit their ideas about how the university could best service their needs.

The lessons learned were interesting and provocative:

- $\quad$ Post-baccalaureate Certificate programs at NJCU would be of interest to their employees.

- When the employer is paying the tuition, those who can meet the academic criteria and who want an MBA would prefer to pursue an MBA at one of the better-known schools in New York City.

- Online classes are helpful and popular with their employees, since driving time at night cuts into the time available for them to study and the time that they want to spend with their families. In addition, business trips are less likely to disrupt their learning.

- The location of the New Jersey City campus was more convenient for most employees than going into New York and required less driving time, so for classroom learning experiences the location would be a plus.

- The University is not well known to the executive level managers in Harborside, most of whom are not from the New Jersey area.

From these findings, it was determined that we should pursue offering Certificate programs and specialty Master's level courses. Based on the overwhelming number employed in the Financial Services industry within the university's service area, a Master of Science in Finance appeared to be the most appropriate. However, with the investment of time and money required for any new program offering, it was decided to assure the accuracy of these observations with a follow-up environmental scan of NJCU graduates and current students, and then, based on that input, expand the environmental scan to potential students in the business community. The Department wanted to see if the perceptions of the business representatives were correct when potential students were asked directly.

\section{Poll of Current Students}

A small mailing to recent graduates was inconclusive, with almost no response. Many were no longer at the address of record, and the response was not valid statistically. However, a poll of juniors and seniors enrolled in 
the Managerial Finance classes indicated that a Master of Science in Finance would have the most appeal for those who thought that they were likely to go to graduate school. The Managerial Finance classes were chosen because

- Managerial Finance is a required course for all Business majors, and therefore represents a cross-section of the various majors.

- $\quad$ There are more sections of that course running in a given term than any other upper level course and

- Most of the students taking the course are seniors and are close to making a decision about attending graduate school.

- Members of a marketing class were given the project of doing the survey to eliminate observational bias on the part of the faculty.

At this point, the task was to determine if potential students and members of the business community would respond the same way. In addition, the faculty had to narrow the possible certificates down to those that would be the most marketable and require the least number of new faculty members.

\section{The Potential Design Unfolds}

From concepts encountered while attending workshops on Teaching, Learning and Assessment, the department faculty, along with the Dean of the College of Professional Studies, wanted to assist students in developing portfolios that demonstrate excellence to potential and present employers. As more information came into the Department concerning the demand for national certification, it was decided that, although there are some concerns about standardized tests as an assessment tool (U. S. Department of Education, 1996), being able to sit for a national certification examination would meet this important University goal. Since these organizations have published topics on which they test and all questions have been reviewed by psychometricians and by content specialists, and have had extensive field testing, there would probably be less bias and more consistency of result than any test that we could develop within the department.

In addition, we hypothesized that a certificate that led to sitting for a national certification would be more marketable than a disembodied certificate that might not have much meaning out of our local area. Regardless of where our graduates relocated in the future, we wanted them to have their work validated.

Finally, it was recognized that there were many popular national certifications in financial disciplines, and that we could possibly incorporate the courses in the Certificate programs into a Master of Science in Finance, with the result that students who completed a certificate would have completed a subset of courses toward the Master of Science. It was also hypothesized that having the certificate courses offered as graduate courses, with the consequent availability of credit toward a Master's degree, would make the certificates more marketable and help attract pre-qualified students into the Master of Science program to make program enrollment viable.

In addition, this strategy would make the best use of our scarce human resources, since there would be both students in certificate programs and students enrolled in the Master's program attending classes taught by only one faculty member. There was a conjecture, never tested, that having the students in the same classes would assure the quality of the certificate offerings, and give the certificate students a chance to interact with those pursuing a Master of Science in Finance, perhaps encouraging them to matriculate.

At this point a questionnaire was developed, along with several relevant databases, to determine if there really was interest in the proposal as it was being envisioned. In the meantime, faculty members started examining the certification requirements and topics for appropriateness to the finance curriculum that we had already envisioned. 


\section{Development of the Questionnaire}

In the development of the Survey Questionnaire for a possible Master of Science in Finance Program, the department asked the following questions:

\section{What are the things that we need to know?}

1. Are there constituencies that would be interested in pursuing a M. S. in Finance?

2. What are the motivators for getting a MS in Finance at NJCU for each constituency?
a. Proximity
b. Availability of Evening classes
c. Availability of Online classes
d. Availability of Study labs in conjunction with online courses
e. State University/low tuition costs
f. Availability of Computer training with program
g. $\quad$ Placement activities
h. Quality of faculty
i. Academic excellence

3. Would offering concentration courses that lead to qualification for a professional certificate in such areas as $\mathrm{CFA} \circledast, \mathrm{CFP} \AA, \mathrm{CMA}$ or $\mathrm{CFM}$ add to the appeal of a Master's program?

4. Would offering a concentration in Entrepreneurship or Small Business operations add to the appeal of a MS in Finance program? (Some members of the small business organization had suggested this.)

5. Would daytime, evening, online courses, or some combination of on-campus and online classes be most appealing?

\section{Who are likely constituencies?}

These were the answers that we hypothesized:

- Business Graduate of NJCU (within last 15 years)

- $\quad$ People in Financial Planning Profession who do not have Masters or CFP

- CPAs interested in Financial Planning

- $\quad$ Corporate Employees in Financial Departments

- Persons who want to be Financial Analysts, Portfolio managers or Investment Advisors

- Stockbrokers

- Insurance Agents

- $\quad$ Attorneys with Estate Planning practices

- $\quad$ Small Business owners

To get as appropriate a sample as possible from these probable constituencies with always scarce resources, the following lists were developed:

- Members of the Northern New Jersey Chamber of Commerce

- $\quad$ Chartered Life Underwriters (Master Life Insurance Agents)

- $\quad$ Certified Public Accountants in Hudson, Essex and Edison counties

- Members of the Financial Planning Association of New Jersey with addresses within selected zip codes in proximity of the University

- $\quad$ Life Insurance Agents

- Bank Investment Representatives

- Bank managers 
The resulting list was more than 1100 people within approximately 30 minutes drive of the University. The questionnaire, along with a complimentary cover letter, was sent to the entire list with a postage-paid reply envelope. The number of replies was excellent - approximately $12 \%$-- and the results confirmed our hypothesis that the national certifications would enhance the appeal of the Master of Science in Finance degree program and would also appeal to people who did not intend to go further academically. The greatest numbers of people were interested in the CFP® professional certification: the CFA® designation was a very close second. More were interested in the CFM designation than those developing the program had expected, since it was our perception that it was a lesser-known credential.

Based on the results of the questionnaire, it was found that while there was some preference for online courses, the difference in number between those desiring online only and those preferring a traditional classroom experience was slight. It was therefore decided, that while we might eventually develop the graduate program into online courses, that initially we would have traditional classroom courses with web-assistance. This would meet the need for those who travel on business to keep up with their classes, and still give the University a chance to become better known to the business community. There was also the benefit of feedback to the faculty developing the new courses to adjust their design. Based on the solid information that had been acquired, it was decided to proceed to the curriculum design stage.

\section{The Choice of Certifications}

Based on a combination of anecdotal evidence, the fit of tested topics with the learning outcomes of a traditional Master of Science in Finance and the skills of existing faculty, it was decided to test the appeal of three financial certifications: the Certified Financial Planner® certification (CFP®), the Chartered Financial Analyst (CFA®) designation, and the Certified in Financial Management (CFM) designation. Among the reasons for these choices were:

- Faculty skills: Among the existing faculty, one faculty member is a Chartered Financial Analyst, and another faculty member is a Certified Financial Planner® professional. Two faculty members are Certified Management Accountants, for which the examination differs only in one section out of four sections from that for the Certified in Financial Management designation examination.

- Known demand for the Certification: According to personal knowledge of the various faculty members, the Certified Financial Planner® certification is being strongly encouraged by several major brokerage firms (such as Merrill Lynch, Raymond James and Paine Webber) and banks (Fleet's Quick \& Reilly subsidiary) for their investment representatives. The Chartered Financial Analyst ${ }^{\circledR}$ designation is one of the most sought after designations in the financial field. The same examination is given internationally, so any person with a CFA ${ }^{\circledR}$ has demonstrated an understanding of the same material, in English, regardless of where they took the exam. The Certified in Financial Management designation is being strongly suggested to all professional members of the treasury departments of major employers in the immediate region, including headquarters of a major pharmaceutical company.

- Rigor and congruence of topics with those in a traditional Master of Science in Finance curriculum. Since a stated objective was that the curriculum should accommodate both students who want to pursue academic goals and students for whom the Masters would be the terminal degree, the career oriented certifications had to meet academic standards. As shown below, the topics required to prepare for the certification tests were quite similar to many of those already in the tentative Finance curriculum.

- Use of existing courses: In addition, some of the courses for the CFM certification already existed in the Master of Science in accounting curriculum, again making the most of department resources.

\section{Congruence of Nationally Recognized Professional Credentials with Traditional Curriculum Design}

One of the major features that makes this curriculum innovative is that the important elements of a traditional Master of Science in Finance are included, so that a student who decides to pursue a terminal degree will not be at a disadvantage, and the needs of students for immediate career advantage are also met. All too often, nonacademic professional credentials are not acknowledged for their business prestige and immediate credibility by 
those in the academic community. Just as a law degree is not validated until the holder passes the bar, a degree from a lesser-known college or university will be enhanced by a related nationally-recognized professional certification or designation, no matter how high the quality of the institution granting the degree.

The certifications chosen were nationally or internationally recognized and test topics strongly related to the learning outcomes desired in a Master of Science. The rigor and discipline of the certifications were strong reasons for the selection of these particular certifications. In the following section, we list the topics covered on the various certification examinations. Academics from the business disciplines will recognize the relationship to traditional topics in finance. In most cases, the curriculum that was designed develops the topic in greater depth than would normally be done in a test preparation program, and covers the theoretical basis more extensively.

\section{Certified Financial Planner ${ }^{\circledR}$ Professional}

Certified Financial PlannerTM professionals are individuals who have met CFP Board's education, examination and experience requirements, are committed to high standards of ethical conduct and who complete CFP Board's biennial certification requirements to use the certification marks CFP ${ }^{\circledR}$, Certified Financial Planner ${ }^{\mathrm{TM}}$. All CFP professionals have voluntarily submitted to the regulatory authority of CFP Board. There are 101 topics covered on the CFP ${ }^{\circledR}$ Certification examination. (CFP Board of Standards, 2003)The topics are divided among the following broad areas.

General Principles of Financial Planning - This area includes the financial planning process, ethics and regulation, personal finance matters such as personal financial statements, budgeting, credit and debt management, time value of money concepts and applications, financial institutions, macroeconomic concepts, business law including implications of various kinds of business entities, property titling, contracts torts and agency and quantitative analysis.

Insurance Planning, Risk Management and Employee Benefits - including principles of insurance, methods of handling risk, analysis and evaluation of risk exposures, legal aspects of insurance, property and casualty insurance, life insurance, health insurance, disability income insurance, long-term care insurance, viatical settlements, insurance needs analysis, taxation of the various types of insurance, policy selection, employee benefits planning, employee stock options, employee stock purchase plans, non-qualified executive deferred compensation, and employer-employee arrangements.

Investment Planning - including Types and use of investment vehicles, types of investment risk, measures of investment risk, measures of investment return, Time-influenced security valuation concepts, Bond and stock valuation methods, portfolio management and measurement concepts, formula investing, investment strategies, asset allocation and portfolio diversification, efficient market theory, asset pricing models including the capital asset pricing model, multi-factor asset pricing model, Black-Scholes option pricing model, Binomial option pricing, leverage of investment assets, hedging and option strategies, tax efficient investing, investment strategies in tax-advantaged accounts, and taxation of investment vehicles.

Income Tax Planning including Income tax law fundamentals, tax compliance, income tax calculations, tax accounting methods, tax characteristics of entities, Income taxation of trusts and estates, basis, cost-recovery concepts, like-kind exchanges, capital gains and losses, depreciation recapture, alternative minimum tax for individuals and businesses, tax management techniques, passive and at-risk rules, tax implications of marriage and divorce, and charitable contributions and deductions for individuals and businesses.

Retirement Planning including retirement needs analysis, Social Security, Medicare, types of retirement plans, qualified plan rules and options, retirement plan design, individual retirement plans, business non-profit retirement plans, feasibility of installation of a qualified plan, ERISA regulations, regulatory considerations of the Department of Labor, fiduciary responsibilities, investment considerations for retirement plans, and distribution rules, alternatives, and taxation.

Estate Planning including methods of property transfer at death, probate process, estate planning documents, gifting strategies, gift taxation and compliance, incapacity planning, estate tax calculation and compliance, state death tax rules, satisfying liquidity needs, powers of appointment, revocable and irrevocable trusts including qualified interest trusts, Crummey trusts, taxation of trusts, charitable giving, valuation issues, marital deduction, Deferral and minimization of estate taxes, Intra-family and other business transfer 
techniques, Disposition of estate, generation-skipping transfer tax (GSTT), fiduciary responsibilities, and income in respect of a decedent.

\section{Chartered Financial Analyst ${ }^{\circledR}$ Charterholder}

Holders of the Chartered Financial Analyst $\left(\mathrm{CFA}^{\circledR}\right)$ designation are securities analysts, money managers and investment advisers who focus predominately on the analysis of investments and the securities of particular companies or industry groups. Individuals earn the CFA designation by completing the Association for Investment Management and Research's ${ }^{\circledR}\left(\mathrm{AIMR}^{\circledR}\right)$ experience, education, examination and ethics requirements. All CFA ${ }^{\circledR}$ charterholders have voluntarily submitted to the authority of AIMR.

The Chartered Financial Analyst (CFA®) Program is a globally recognized standard for measuring the competence and integrity of financial analysts, administered by the Association for Investment Management and Research (AIMR). The CFA curriculum develops and reinforces a fundamental knowledge of investment principles. Three levels of examination, Level 1, 2 and 3, measure a candidate's ability to apply these principles at a professional level. The CFA exam is administered once a year in early June in more than 70 nations worldwide.

The CFA Exam is given in three levels, each with its own separate examination. Candidates are only allowed to sit for only one examination each year, and must pass each level sequentially, and must fulfill other requirements of the program, before earning the right to use the CFA charter. The Graduate Certificate in Financial Analysis at New Jersey City University will prepare the student to sit for the Level I examination. The complete Master of Science in Finance would be expected to qualify students for the Level II examination. The Level III examination will require further preparation.

\section{CFA Level I Topics and Readings (AIMR, 2002)}

Ethical and Professional Standards - Standards of Practice Handbook, 8th edition, 2003 CFA Level I Candidate Readings: AIMR Performance Presentation Standards Handbook, pp. 1-25

Quantitative Methods - Quantitative Methods for Investment Analysis (DeFusco, McLeavey, Pinto \& Runkle), Ch. 1, 3-8

Economics - Economics: Private and Public Choice, 9th ed. (Gwartney, Stroup \& Sobel), Ch. 12-15, 17-23, 2002 CFA Level I Candidate Readings: Shapiro

Financial Statement Analysis - The Analysis and Use of Financial Statements, 2nd ed. (White, Sondhi \& Fried), Ch. 2, 3, 6-11, Investment Analysis and Portfolio Management, 6th ed. (Reilly \& Brown), Ch. 12, 2003 CFA Level I Candidate Readings: White, Sondhi \& Fried; Kieso \& Weygandt

Corporate Finance - Fundamentals of Financial Management, 8th ed. (Brigham \& Houston), Ch. 1, 9-14, Quantitative Methods for Investment Analysis (DeFusco, McLeavey, Pinto \& Runkle), Ch. 2

Markets and Instruments - Investment Analysis and Portfolio Management, 6th ed. (Reilly \& Brown), Ch. 4, 5,7

Equity Investments - Investment Analysis and Portfolio Management, 6th ed. (Reilly \& Brown), Ch. 13, 18-21, Quantitative Methods for Investment Analysis (DeFusco, McLeavey, Pinto \& Runkle), Ch. 2

Debt Investments - Fixed Income Analysis for the Chartered Financial Analyst Program (Fabozzi), Ch. 1-7, Quantitative Methods for Investment Analysis (DeFusco, McLeavey, Pinto \& Runkle), Ch. 2

Derivative Investments - Futures, Options \& Swaps, 3rd ed. (Kolb), Ch. 1, 2, 10, 11, 20

Alternative Investments - Investment Analysis and Portfolio Management, 6th ed. (Reilly \& Brown), Ch. 26, 2003 CFA Level I Candidate Readings: Gitman \& Joehnk; Schilit; Barry

Portfolio Management - Investment Analysis and Portfolio Management, 6th ed. (Reilly \& Brown), Ch. 1, 2, 3, 8, 9, 2003 CFA Level I Candidate Readings: Shapiro

\section{Certified in Financial Management certification(IMA, 2003)}

Holders of the CFM certification are persons interested in accounting and financial management for businesses. They include accountants, bank managers, and corporate financial management professionals. They have 
met requirements of education and experience and have successfully passed the Certified in Financial Management examination. They agree to abide by certain ethical standards. They must be members of the Institute of Management Accountants and have voluntarily chosen to submit to the authority of the IMA.

The entire topic list for the CFM certification examination is quite lengthy - 70 pages of 10 point type, but the list below condenses the master list into major topics. In some cases the order was changed slightly from the IMA list to show congruence with the traditional finance curriculum.

\section{Part 1 - Economics, Finance and Management}

A. Microeconomics Factors affecting the individual firm including demand, supply, elasticity, and their interaction; consumption of goods; production factors and their cost; market structures and pricing; various economic markets including the demand for resources and the labor market.

B. Macroeconomics Issues in macroeconomics such as inflation, employment, and economic growth; the nature of business cycles and reasons for fluctuations; fiscal and monetary policies.

C. International Business Environment Comparative advantages of trade; free trade and protectionism; barriers to international trade; nature and theory of foreign exchange; international capital investment and global standards.

D. Domestic Institutional Environment of Business Legal environment of business including the legal forms of business and the structure of government regulation; the impact on business of external forces including employee protection, antitrust policies, social legislation, and non-governmental groups such as consumer and environmental organizations, and financial institutions; social responsibility.

E. Working Capital Policy and Management Evaluating optimum levels of current assets and current liabilities and balancing profitability and risk; policies for the management of cash, marketable securities, accounts receivable, and inventories; short-term credit for financing current assets.

F. Long-Term Finance and Capital Structure Factors influencing the optimum capital structure including types of risk and leverage; objectives and policies of long-term financing; cost of capital; types of long-term financing instruments; dividend policies.

G. Organizational Structures, Management, and CommunicationNature of organizational decision making; structural evolution in organizations; characteristics of effective organizations; jobs, teams, and the roles of managers; human resources, leadership styles, and motivational theories and methods; communication models, and managing communication and information content.

\section{Part 2 Corporate Financial Management}

A. Use of Financial Statements Principal financial statements and their purposes; the annual report; special topics in financial statements such as segment reporting, leases, pensions, and retained earnings.

B. Advanced Topics in Corporate Financial Management Capital instruments for long-term financing; dividend policy; optimum capitalization; financial markets; interest rates; investment banking relationships; commercial banking relationships; administration and compliance for finance instruments; comparative financial statement analysis; business combinations; and corporate restructuring.

C. Risk Management Types of risk; measures of risk; portfolio management; options and futures; corporate and product liability insurance; foreign currencies and foreign exchange.

D. External Financial Environment Investor and shareholder relations; the effect of government regulations; the effect of international regulations on business.

E. Accounting Standard Setting Environment Objectives and users of external financial statements; development and application of public reporting standards; conceptual framework for financial accounting; the SEC and its reporting requirements. 


\section{Part 3 Management Reporting, Analysis, and Behavioral Issues}

A. Cost Measurement Cost concepts, flows and terminology; alternative cost objectives; cost measurement concepts; cost accumulation systems including job order costing, process costing, and activity-based costing; overhead cost allocation to cost objectives.

B. Planning Panning process, purposes of planning and budgeting; budgeting concepts; annual profit plans and supporting schedules.

C. Control and Performance Evaluation Factors to be analyzed for control and performance evaluation including revenues, costs, profits, and Investment in assets; techniques to control and evaluate operations including variance analysis based on flexible budgets and standard costs; techniques to evaluate and report performance including responsibility accounting for revenue, cost, contribution and profit centers; quality considerations.

D. Behavioral Issues Alignment of managerial and organizational goals; behavioral issues in developing and using budgets and standards; behavioral issues in reporting and performance evaluation.

\section{Part 4 Decision Analysis and Information Systems}

A. Decision Theory and Operational Decision Analysis Logical steps to reach a decision; relevant data concepts; cost, volume, profit analysis; marginal analysis; cost-based pricing. Income tax implications for operational decision analysis.

B. Investment Decision Analysis Cash flow estimates; time value of money; discounted cash flow concepts; net present value; internal rate of return; and non-discounting analysis techniques. Income tax implications for investment decision analysis.

C. Quantitative Methods for Decision Analysis Quantitative methods and techniques including regression analysis, learning curves, linear programming, sensitivity analysis, network analysis, probability concepts and expected values, decision trees, simulation, and other appropriate aids to decision making.

D. Information Systems Nature of management and accounting information systems; systems development and design; techniques and terminology applicable to the development of computer-based accounting information systems; systems controls and security measures.

E. Management Controls Internal control environment, procedures, and standards; responsibility and authority for internal auditing; types of audits and audit reports; assessing the adequacy of the accounting information system.

*Source: Institute of Management Accountants, www.imanet.org.

\section{Student Portfolios, Assessment and Learning Outcomes}

At this point, the major elements of the curriculum design were decided, and it was time to move to course design. Rather than having a list of courses with no integration, the university desired a program that would achieve goals of synthesizing the diverse topics and courses into a coherent whole, regardless of which concentration was chosen. There was also a desire to have continuous feedback to the students on their progress, and to have them have more than a grade to show their employers, many of whom are paying for the courses.

\section{Portfolios}

The development of a diverse student portfolio was chosen as one way to provide that feedback. One of the key concepts of a portfolio is that the student will be given feedback by the instructor on how to improve the items in the portfolio. Portfolios are collections of student work representing a selection of performance. Portfolios developed from artistic portfolios designed to showcase artists' accomplishments and personally favored works. A portfolio may be a folder containing a student's best pieces and the student's evaluation of the strengths and weaknesses of the pieces. It may also contain one or more works-in-progress that illustrate the creation of a product, such as an essay, evolving through various stages of conception, drafting, and revision.(U. S. Department of Education 1993) 
The concept of student portfolios is part of the movement toward student-centered assessment in higher education. At some institutions, traditional grades have been replaced by electronic student portfolios developed over the course of the college career. In the opinion of the Department of Business Administration faculty, this movement, while laudable and in many cases more informative than traditional grades, was most suitable for residential colleges and universities where students attended school over a set period of time. It was not judged practical for our students, however, many of whom are adults juggling careers and responsibilities as parents along with their education, and whose time in the program may vary dramatically.

Portfolios are more work for the professor and they involve more writing by the student, even in quantitative classes. (Knoerr \& McDonald, 1999) The fact remained that the idea of the student developing a portfolio of sample work to show a potential employer or client is valid and intriguing. It was decided that we would introduce the concept of portfolios in the very first course in the program, and let the students keep their portfolios themselves. Students would be able to bring their portfolios to their advisers for commentary and upgrade.

\section{Rubrics as Part of Course Design}

Another innovative factor in course design was the incorporation of university rubrics for core competencies. As part of its commitment to the 9 Principles of Good Practice for Assessing Student Learning (American Association for Higher Education, 2003), New Jersey City University has developed rubrics in seven different competencies that are to be used by faculty as standards in all disciplines.(New Jersey City University Faculty, 2003) The competencies include Oral Communication, Written Communication, Information Literacy, Quantitative Analysis, Technology Literacy, Critical Thinking and Ethics.

These were developed at the undergraduate level, but it was decided to incorporate at least one competency rubric in each course in the new graduate program. The rubrics outline four levels of competency: Novice, Proficient and Accomplished. Samples of the rubrics, which are extensive documents, are available by request to the author.

It was decided that each course would concentrate on one rubric in addition to course content, as appropriate to the topic. For example, a course that required a research paper would probably concentrate on written communication or critical thinking. A course such as portfolio theory, which requires a substantial understanding of mathematical concepts, would incorporate the rubric for quantitative analysis. Professors would be free to include additional rubrics as desired and as deemed appropriate for their style of teaching.

The University does provide an electronic portfolio for recording student performance on the rubrics. Use of this portfolio is voluntary for the faculty member. Over time, if enough members of the faculty choose to use the electronic portfolio for the rubrics, a student will develop an electronic portfolio. At this point, the electronic portfolios are primarily for research purposes, but they could develop over time in a more powerful assessment and reporting method. Discussion with faculty members yielded the conclusion that letting the student keep their own portfolio was the most workable method at this time, as professors incorporate rubrics into their syllabi and try different methods of using them that work with the manner in which they deliver course content and elicit response from the students.

\section{Case Studies}

After consideration of additional ways in which to help students develop portfolios and critical thinking skills, it was decided that case studies give the students the most opportunity to demonstrate integration of discrete topics, critical thinking, presentation skills and information literacy, and would also give students the opportunity to develop a portfolio of work. In the spirit of student-centered assessment, the rubrics for the competencies emphasized in that course would be presented to the students at the beginning of the term and the concept of a student portfolio explained to them. In this way, the students would take charge of relating their school work to their careers, and would write and present their case studies in a manner not designed just for college, but for future use outside the university setting. Writing case studies is grueling work, but fortunately, the use of the credentials led to 
the discovery of a large body of case studies designed for those credentials that would also be appropriate for the academic setting. Combined with case studies already developed for such courses as financial modeling and portfolio analysis, there were enough case studies already developed that new ones could be developed over time and would not be required initially.

Part of the assessment of the case studies in a particular course will be on how well they incorporate the highlighted rubric. Written and oral communication skills were part of almost every course, and critical thinking was also emphasized by the faculty members writing the courses. One of the major learning outcomes mentioned by every person associated with this project was that no student should graduate without the ability to prepare a comprehensive financial presentation that demonstrates logic flow and coherent explanation in appropriate language. Graphs and figures should be clear and comprehensible, and relate to the text.

Understanding of the idea of the rubrics in core competencies, and the acceptance of the idea of a portfolio of work has been enthusiastically embraced by our students so far. The rubrics give them a sense of control over their own destinies, since they understand exactly what is expected, and the portfolio idea is universally considered to be a help in their careers. There is opportunity for more study of how these ideas work in practice, as the incorporation of the notion of rubrics and portfolios in graduate study seems largely unexplored.

The final modification to the traditional curriculum was the use of a major case study project instead of a traditional thesis. Since for most students in the program, the MSF will be a terminal degree, a case study with sufficient detail, need for research and presentation requirements will demonstrate scholarship in the same manner that an academic research paper does, and have more applicability to their chosen careers. This case study will be the focus of a capstone course, and will incorporate the entire curriculum. This final project will be evaluated by two or more faculty members, and will be expected to demonstrate mastery of both theory and application. Although the case study project will be the default in the capstone course, a student desiring to continue to a doctorate will be given the opportunity to prepare a traditional thesis under the guidelines developed by the College of Professional Studies. In either case, the final project developed in the capstone course will be the ultimate item in the student's portfolio and should demonstrate in one document their accomplishment.

\section{Conclusion and Opportunities for Application in other Disciplines}

While the process followed would clearly work in the financial field, it is more important to evaluate if the process would work in other disciplines. An analysis of the steps followed reveals that there are several elements of this design process that would be applicable regardless of discipline or curriculum content:

\section{New Jersey City University spent the time to learn the needs of its constituency.}

- $\quad$ Members of the business community and potential students were asked what they wanted. While there were costs associated with this process, they were modest relative to the costs of developing a program that was neither wanted nor needed.

- Starting with a focus group gave us a great deal of qualitative information quickly and indeed changed our preconceived notions of what was wanted. The resources of the President's office were used to get high-ranking participants, and the good will that letting these individuals speak their minds created for the university alone was worth the cost.

- Including a prepaid return envelope increased the response to our questionnaire. Prior mailings that had been tried had not included a prepaid envelope, and the returns were less than one-third the response to this questionnaire.

- $\quad$ Using the polling of present seniors and junior as a marketing class project elicited more candid and honest responses than had the faculty done the poll themselves, plus was an excellent learning experience for the students. Much higher quality information was obtained in this manner. 
There was a willingness to think outside the box and come up with an innovative design appropriate to our community

- It was a given that we would not compromise our academic standards, but as a state institution, New Jersey City University has a mandate to serve the needs of its community. The faculty recognizes that not being demanding of students prevents them from reaching their full potential, and wanted to respond to the student needs without marginalizing them.

- We looked for a way of providing the career-enhancing features the potential students wanted, without compromising our standards. There was great skepticism about using an external exam as even one portion of the assessment of students, but as the comparison of topics covered on the examinations and our desired learning outcomes was conducted, we gradually saw the congruency and how the preparation could be incorporated without undue influence.

\section{Having faculty members familiar with the external certification was extremely helpful}

- $\quad$ The known professionalism, professional contacts and ability to relate the academic to the external of our faculty members who had earned the additional external credentials made the entire process easier. For other disciplines, the suggestion would be to look at the published topics tested on wellrecognized certifications in your discipline, and similarly relate those topics to your desired learning outcomes. If they are congruent, then this aspect of the curriculum design could be applicable. Polling your faculty for any external designations they hold is a good start on the process.

\section{Rubrics for core competencies enhanced course design}

- We were able to explore topics listed for the examinations, compare them to our desired learning outcomes and bring them into full blossom as learning outcomes at the highest levels of the revised Bloom's taxonomy using the rubrics as guidelines. We are finding that sharing the rubrics with the students at the beginning of the term helps them understand the level of competency expected of them and how to achieve at that level.

\section{Student portfolios are a recognized plus when mentioned to potential students}

- It is not difficult to explain portfolios to students. They immediately see the personal advantages, and it tends to make them more careful and creative than they would have something seen only as a classroom assignment. Art students have long recognized the value of their portfolio, now students in other disciplines are recognizing them also.

\section{References}

1. AIMR. (2002). CFA candidate body of knowledge. Retrieved December 10, 2003, 2003, from http://www.aimr.com/pdf/cfaprogram/cbok.pdf

2. American Association for Higher Education. (2003). 9 Principles of Good Practice for Assessing Student Learning. Retrieved December 10, 2003, 2003, from http://www.aahe.org/assessment/principl.htm

3. CFP Board of Standards, I. (2003). Topic List for CFP® Certification Examination. Retrieved December 10, 2003, 2003, from http://www.cfp.net/downloads/guide_FPTopics.pdf

4. IMA. (2003). Exam content overview. Retrieved December 10, 2003, 2003, from http://www.imanet.org/ima/sec.asp?TrackID=\&CID=53\&DID=1423\&VID=1

5. Knoerr, A. P., \& McDonald, M. A. (1999). Student assessment through portfolios. In E. Bonnie Gold, E. Sandra Z. Keith \& E. William A. Marion (Eds.), Assessment Practices in Undergraduate Mathematics (pp. 350). Washington, DC: The Mathematical Association of America.

6. New Jersey City University Faculty. (2003). Competency Rubrics. Unpublished.

7. U. S. Department of Education. (1996). What the research says about student assessment. Retrieved December 10, 2003, 2003 
8. U. S. Department of Education. (1993). Student Portfolios: Classroom Uses. Retrieved December 10, 2003, 2003, from http://www.ed.gov/pubs/OR/ConsumerGuides/classuse.html 